\title{
ANALISA DAN PENDATAAN PENYEBARAN TENAGA TERDIDIK TIDAK PRODUKTIF MENGGUNAKAN SISTEM PEMETAAN WILAYAH ONLINE
}

\author{
Hidayatulah Himawan \\ Jurusan Teknik Informatika UPN "Veteran" Yogyakarta \\ Jl. Babarsari 2 Tambakbayan 55281 Telp (0274) 485323 \\ email: if.iwan@gmail.com
}

\begin{abstract}
Advances in technology are getting better can be used to manage and analyze the existence of the spread of educated unproductive or unemployment in certain regions. More information system used to provide information about the status and presence and skill of each person, so hopefully with this system, managing and planning the handling model unemployment will be better targeted. Information system developed using the model of geographic information systems (GIS). Mapping areas using GIS over the provision of information to the spread of the data. The research method used is the waterfall model, where the system is planned and developed with the concept of handlers per area of any constraints. This research synergies between the variables that are used as analysis of population number, and the model needs and ordinances existing handlers.
\end{abstract}

\section{Keywords: information systems, GIS, Mapping Regional Analysis, Waterfall}

Kemajuan teknologi yang semakin baik dapat dimanfaatkan untuk mengelola dan menganalisa keberadaan penyebaran tenaga terdidik tidak produktif atau pengangguran di wilayah tertentu. Sistem informasi yang digunakan lebih kepada pemberian informasi tentang status dan keberadaan serta keahlian setiap orang, sehingga diharapkan dengan adanya sistem ini, pengelolaan dan perencanaan terhadap model penanganan pengangguran tersebut akan lebih tepat sasaran. Sistem informasi yang dikembangkan menggunakan model sistem informasi geografis (SIG). Pemetaan daerah menggunakan SIG lebih kepada pemberian informasi terhadap penyebaran data yang ada. Metode penelitian yang digunakan adalah waterfall model, dimana sistem direncanakan dan dikembangkan dengan konsep penangan per wilayah dari setiap kendala yang ada. Penelitian ini menghasilkan sinergi antara variabelvariabel yang digunakan seperti analisa jumlah kependudukan, kebutuhan dan model serta tata cara penangan yang ada.

Kata kunci : sistem informasi, SIG, Analisa Pemetaan Wilayah, Waterfall

\section{PENDAHULUAN}

Perkembangan ilmu pengetahuan dan teknologi yang semakin maju, membuat setiap lini kehidupan di dalam bermasyarakat dalam berinteraksi menjadi lebih mudah. Teknologi yang dikembangkan selalu berupaya memberikan pelayanan dan informasi yang optimal bagi setiap pengguna. Salah satu yang selalu dikembangkan adalah informasi tentang keberadaan dan status bagi seorang penduduk dilingkungan masyarakat. Hampir disetiap instansi pemerintah telah merasakan dampak dari kemajuan teknologi Dengan kemajuan teknologi, inovasi dan efesiensi terus dilakukan untuk menunjang kinerja para pegawai dalam melakukan berbagai hal.

Salah satu pemanfaatan dalam teknologi dan sistem informasi adalah pengembangan sebuah sistem yang dapat mengidentifikasi keberadaan status terutama tentang kemampuan dan keahlian yang dimiliki oleh seseorang di lingkungan sekitanya. Banyak wilayah yang kurang memperhatikan keberadaan para tenaga terdidik khususnya para sarjana, yang belum mendaptkan pekerjaan, sehingga kebutuhan akan pendataan tenaga terdidik tidak produktif menjadi hal yang sangat penting. Hal ini disebabkan pemerintah daerah khususnya, dalam menyalurkan setiap model peningkatan kemampuan bermasyarakat harus lebih baik, sehingga 
proses pemodelam dan peningkatan kerja sama antar instansi akan menjadi lebih tepat sasaran.

Instansi yang sering terlibat dalam proses pengembangan dan kemampuan serta keahlian masyarakat adalah Dinas Tenaga kerja dan Transmigrasi. Pada instansi ini, model pengembangan sistem menjadi hal yang sangat penting. Mengingat pada Dinas Tenaga Kerja dan Transmigrasi harus memiliki sumber informasi dan data yang akurat terhadap penyebaran tenaga terdidik non produktif pada setiap daerah dan wilayah yang menjadi tanggung jawabnya. Dinas Tenaga Kerja dan Transmigrasi yang menjadi salah satu instansi pemerintah yang berperan dalam pengadaan pegawai, pelatihan pegawai sampai mutasi pegawai pemerintah, mempunyai kedudukan dan fungsi yang sangat penting dalam pemerintahan Republik Indonesia. Oleh karena itu Disnakertrans perlu mengikuti perkembangan teknologi.

Pengembangan sistem informasi pendataan tenaga terdidik tak produktif ini menggunakan Sistem Informasi Geografis berbasis web, sehingga bisa diakses oleh setiap komponen masyarakat yang membutuhkannya. Diharapkan dengan pengembangan informasi yang berbasis web ini, masyarakat bisa lebih memahami fungsi dan kinerja Dinas tenaga kerja dan Transmigrasi dalam menyalurkan setiap kebijakan yang ada.

\section{RANCANGAN DAN DESAIN}

Perancangan pada proses yang dikembangkan pada sistem ini menggunakan 2 (dua) model, yaitu perancangan Entity Relationship Diagram (ERD) dan Data Flow Diagram ( DFD).

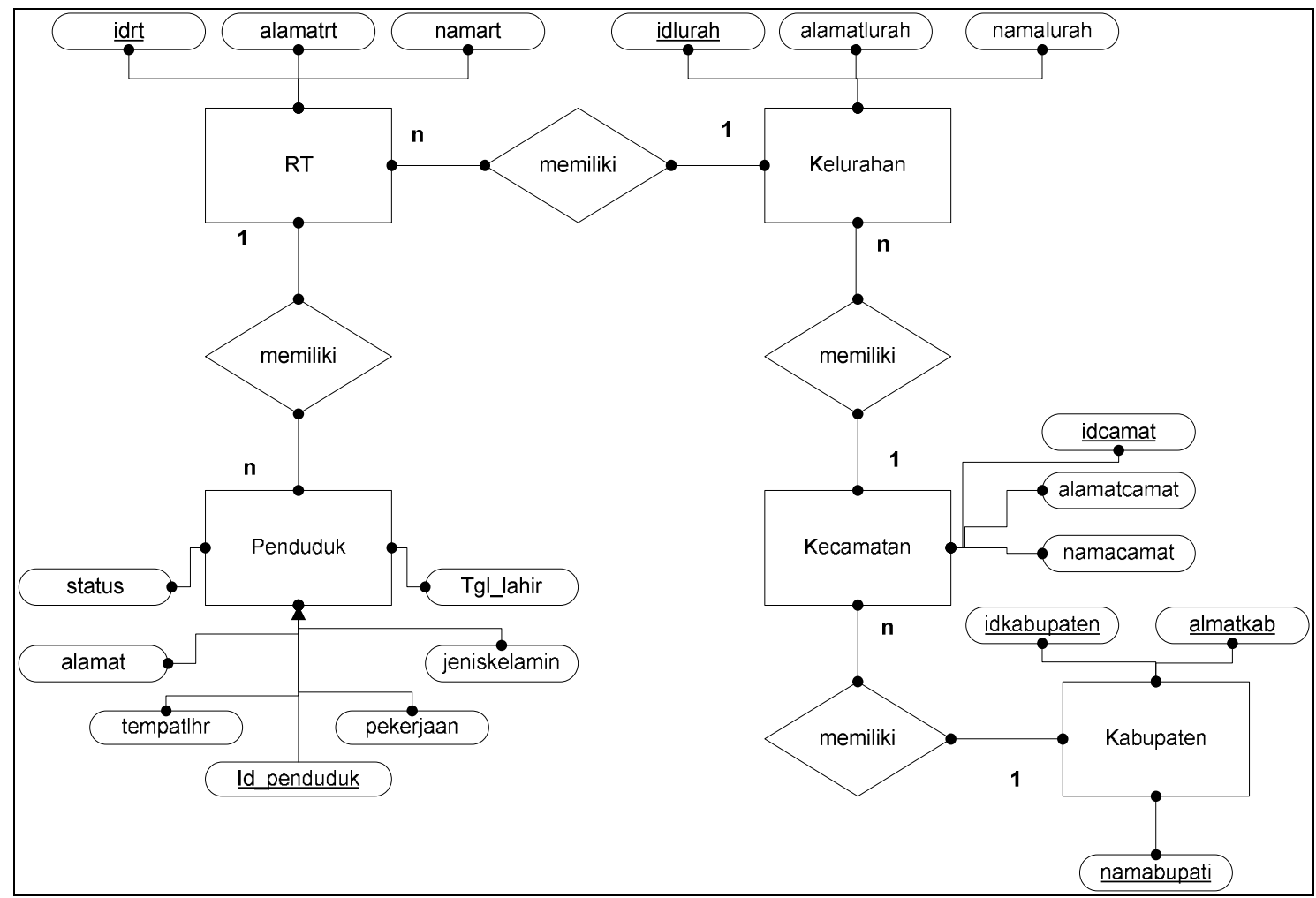

Gambar 1. Entity Relationship Diagram

Pada gambar 1 terlihat bahwa Proses Perencanaan ERD merupakan salah satu bentuk pemodelan yang menggambarkan kebutuhan informasi dalam Sistem Informasi Pemetaan Jumlah tenaga terdidik tidak produktif yang terdapat pada setiap wilayahnya. Beberapa komponen yang saling memiliki keterkaitan dan hubungan diantara setiap data menjadi lebih penting, sehingga para pengambil kebijakan akan menjadi lebih jelas untuk mengetahui keberadaan dan kemampuan yang diliki oleh setiap orangnya. 
Pada perancangan data flow diagram (DFD) yang mengikuti alur kerja sistem lebih kepada untuk menggambarkan asal data, tujuan penyimpanan data, proses yang akan menghasilkan data dan interaksi antara data yang tersimpan dalam proses sistem.

Dalam Aplikasi Sistem informasi yang dikembangkan, proses berjalan melalui beberapa tahapan dan tingkatan, namun pada jurnal ini, proses alur data yang akan diberikan hanya pada tataran DFD level 0.

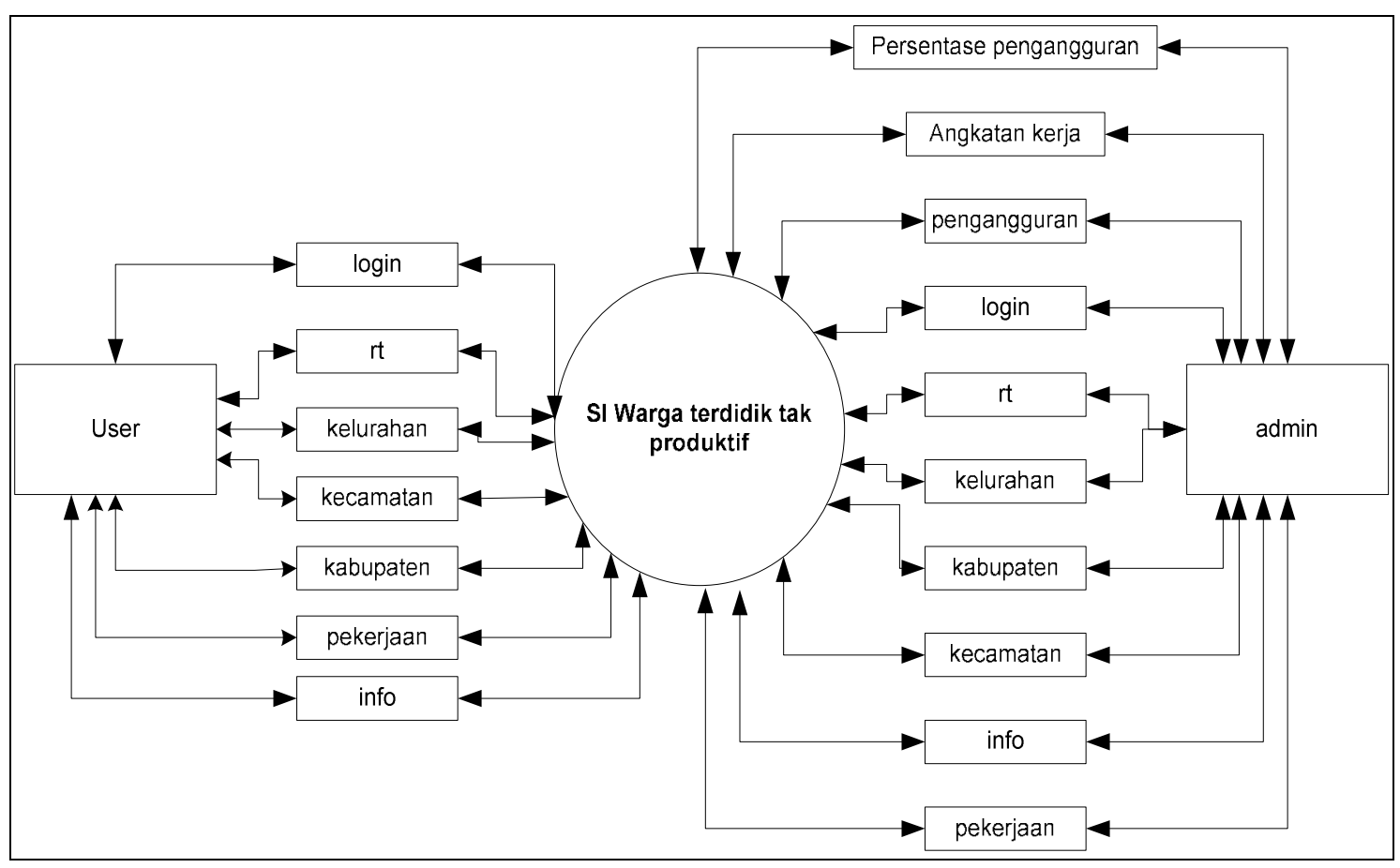

Gambar 2. DFD Level 0

Pada DFD Level 0 ini terdapat dua buah entitas, yaitu entitas User dan entitas Admin, serta terdapat satu buah proses yaitu Sistem informasi Warga Terdidik tak produktif. dimana Proses tersebut user memiliki proses untuk bisa mendapatkan informasi tentang login, rt, kelurahan, kecamatan, kabupaten, pekerjaan dan info. User dapat melakukan proses olah terhadap data pribagi yang dimilikinya, sehingga proses pendataan akan menjadi lebih tepat sasaran karena masyarakat terlibat langsung dalam memberikan informasi dan keberadaan mereka yang sebenarnya.

Entitas admin dapat melakukan beberapa proses dan pengolahan data. Diantaranya memverikan prosentase dan besaran jumlah pengangguran yang terdapat pada setiap wilayahnya, jumlah angkatan kerja yang ada di wilayah tertentu, jumlah tenaga pengangguran sesuai dengan klasifikasi dan pengelompokan kemampuan serta keahliannya, login, rt, kelurahan, kabuoateb, kecapatan, info serta pekerjaan dari masyarakat.

Kedua entitas tersebut melakukan proses pada sistem yang berjalan, sehingga user khususnya para pengambil kebijakan akan dapat terbantukan atas informasi yang diberikan.

\section{IMPLEMENTASI}

Implementasi sistem informasi pendataan penyebaran tenaga terdidik tak produktif menggunakan pemetaan wilayah online berbasis sistem informasi geografis (SIG) memiliki beberapa fasilitas dan menu yang bisa digunakan oleh pengguna. Beberapa bagian yang bisa dimanfaatkan seperti halaman utama bagi pengguna, halaman login bagi yang memiliki hak akes, halaman perwilayah kabupaten yang memberikan informasi penyebaran terhadap tenaga terdidik tak produktif, serta beberapa menu dan fasilitas lainnya yang bisa dimanfaatkan secara langsung oleh para masyarakat. 
Pendataan tenaga terdidik ini dapat dibagi berdasarkan wilayah yang dikehendki, sehingga informasi yang diberikan akan menjadi lebih tepat sasaran. Halaman ini dapat dilihat pada gambar 3.

\section{SISTEM INFORMASI PEMETAAN JUMLAH PENGANGGURAN}

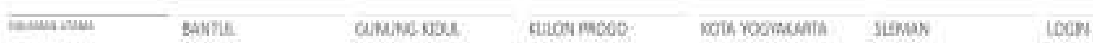

\section{Dinas Tenaga Kerja Dan Transmigrasi}
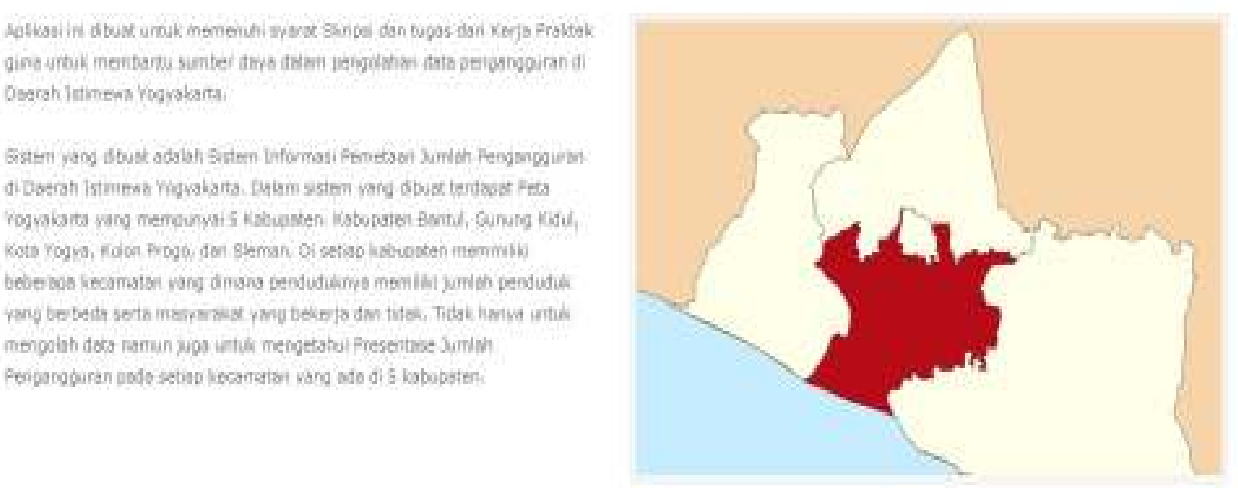

\section{Gambar 3. Halaman Utama}

Pada gambar 3 yang merupakan menu halaman utama terdapat sekilas profil aplikasi dan peta dari daerah yang dikembangkan, serta beberapa link yang terhubung dengan beberapa daerah yang memiliki sistem pendataan terhadap tenaga terdidik tak produktif.

Pada gambar 4 terhadap halaman menu login bagi para pengguna yang memiliki hak akses, sehingga untuk mendapatkan informasi yang lebih lengkap serta pengelolaan data yang lebih baik, maka dapat menggunakan halaman menu login ini.

\section{SISTEM INFORMASI PEMETAAN JUMLAH PENGANGGURAN}

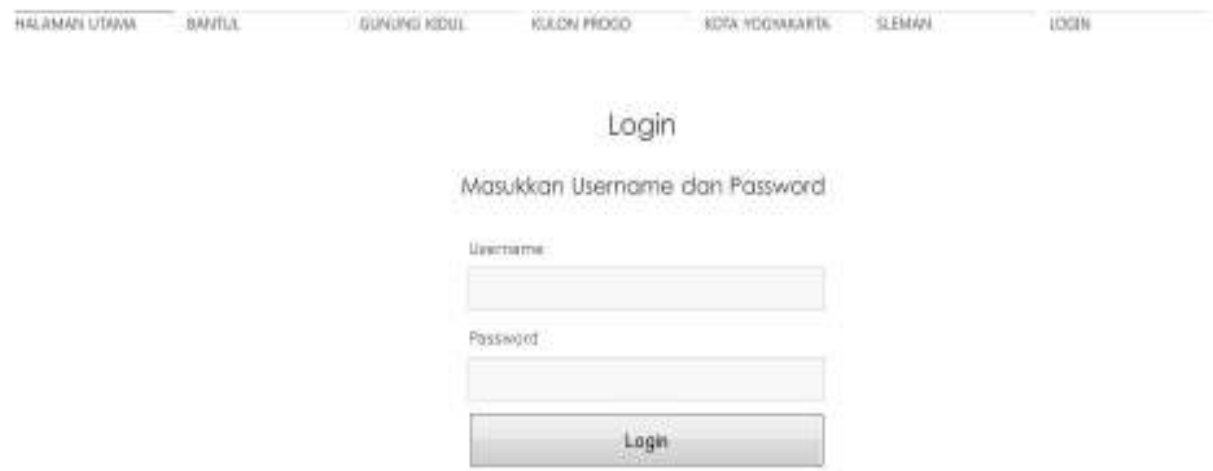

Gambar 4. Halaman Login 


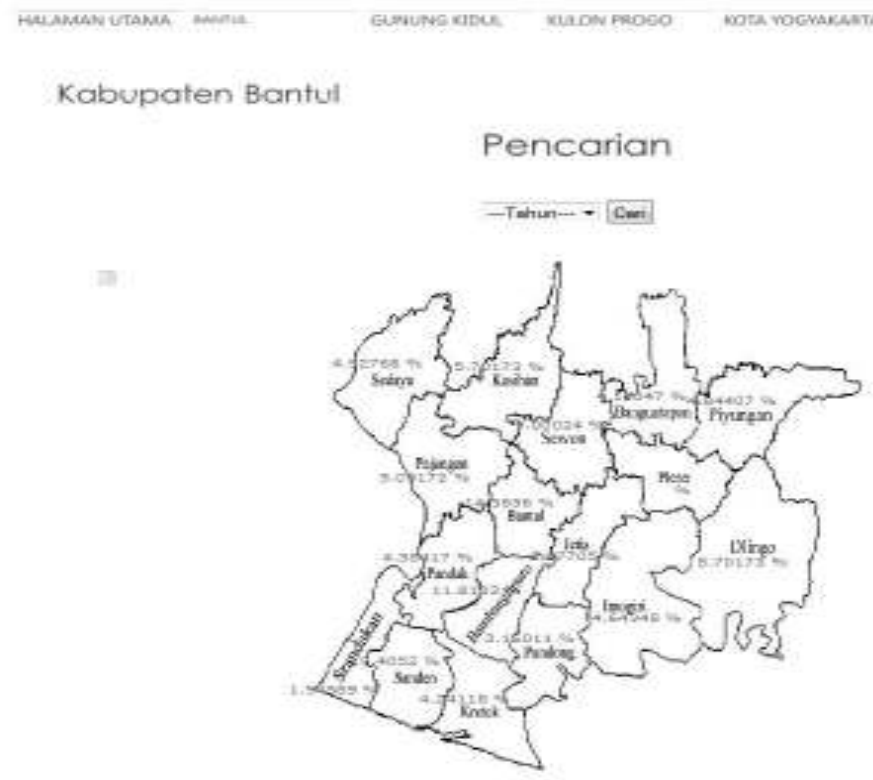

Gambar 5. Halaman Pencarian data penyebaran

Pada gambar 5 terlihat proses pemetaan berdasarkan wilayah untuk melakukan proses pencarian terhadap data tenaga terdidik pada wilayah tertentu.

SISTEM INFORMASI PEMETAAN JUMLAH PENGANGGURAN

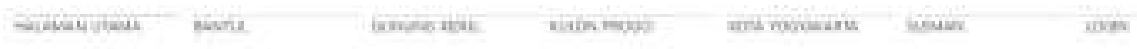

Data Fengangguran don Angokaton Kerjo Kabupaten Bantul

Pencorian

$\rightarrow$ Pin koconots:- - Cos

\begin{tabular}{|c|c|c|c|c|c|}
\hline $\begin{array}{c}\text { Kodes } \\
\text { Kacamatan }\end{array}$ & kucamatis & Tann & - Pengangguran & Eedivirja & $\begin{array}{l}\text { Preasuntates } \\
\text { pongailgguran }\end{array}$ \\
\hline ज्ञाठव & Eambandipurs & 2026 & 2027 & 2471 列 & 1) H1日3 5 \\
\hline
\end{tabular}

1is zeatis

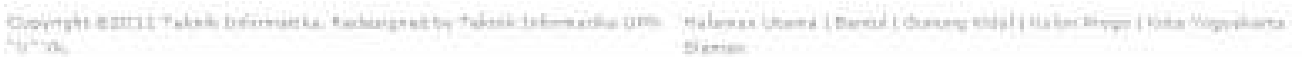

Gambar 6. Halaman Data Persentase

Pada gambar 6 terlihat jumlah persentase penyebaran data tenaga terdidik dan pengangguran di setiap wilayahnya. Persentase ini didasarkan pada perhitungan perbandingan antara tenaga terdidik yang bekerja terhadap pengangguran, sehingga hasil akhir dari persentase yang dihasilkan akan memperoleh sebuah analisa untuk tindak lanjut terhadap penangan, pengelolaan dan peningkatan keahlian serta kemampuan bagi masyarakat yang membutuhkannya. 


\section{KESIMPULAN DAN SARAN}

Dari pengembangan sistem informasi keberadaan tenaga terdidik tak produktif ini, maka dapat diambil kesimpulan sebagai berikut :

a. Dengan adanya Sistem linformasi ini dapat membantu kelancaran para pengambil kebijakan untuk memberikan model dan sistem yang lebih tepat guna untuk meningkatkan kemampuan serta keahlian masyarakat sesuai dengan bidangnya

b. Dengan menggunakan teknologi yang ada, diharapkan kendala dalam penyaluran bantuan dan pelatihan kepada masyarakat khususnya penanganan penyaluran pelatihan akan menjadi lebih baik.

\section{DAFTAR PUSTAKA}

Aditya L.R., Open Source GIS : Aplikasi Quantum GIS Untuk Sistem Informasi Lingkungan, Pusat Studi Lingkungan Hidup UGM, Yogyakarta, 2009

Jogiyanto H.M., "Analisis dan Desain Sistem Informasi: Pendekatan Terstruktur", Edisi Pertama, Andi Offset, Yogyakarta, 1993

Kadiman, Kusmayanto. 2006. Penelitian, Pengembangan dan Penerapan IImu Pengetahuan dan Teknologi Bidang Teknologi Informasi dan Komunikasi Tahun 2005-2025. Jakarta: Kementrian Negara Riset dan Teknologi Republik Indonesia.

Modul Praktikum Pemrograman WEB Jurusan Teknik Informatika Fakultas Teknik Industri Universitas Pembangunan Nasional "Veteran" Yogyakarta 2011.

Modul Praktikum Basis Data Jurusan Teknik Informatika Fakultas Teknik Industri Universitas Pembangunan Nasional "Veteran” Yogyakarta 2011.

Polyviou, Zachos A. 2007. The Information Society: Advantages and Disadvantages. Cyprus: University of Wales.

Prahasta E., Sistem Informasi Geografis konsep-Konsep Dasar (Perspektif Geodesi dan Geomatika), Informatika, 2009.

Wijaya, Stevanus Wisnu. 2006. Kajian Teoritis Technology Acceptance Model Sebagai Model Pendekatan Untuk Menentukan Strategi Mendorong Kemauan Pengguna Dalam Menggunakan Teknologi Informasi dan Komunikasi. Prosiding Konferensi Nasional Sistem Informasi. Yogyakarta. 